\title{
Na Corda bamba de Lygia: os traços de Bildungsroman no romance bojunguiano
}

\author{
Thayná Cavalcante Marques*
}

RESUMO: Esta pesquisa busca compreender as semelhanças e as diferenças entre os processos de formação de um Bildungsroman alemão e aquele aplicado à Literatura juvenil contemporânea brasileira. Assim, empenha-se o conceito de Bildungsroman socio-historicamente compreendendo suas características, delineando a sua preocupação com formação, estabelecendo ligação com os intentos da vertente brasileira. A fim de exemplificar as afirmações feitas, recorre-se ao romance Corda bamba (2002), de Lygia Bojunga Nunes. A intenção é explicar que, apesar de a formação nessa literatura se dar diferentemente daquela estabelecida, ainda assim se classifica como formadora. Como base teórico-crítica: Lukács (2000), Ariès (2011), Maas (2000), entre outros.

Palavras-chave: Bildungsroman. Literatura infantil e juvenil. Lygia Bojunga Nunes. Literatura comparada.

ABSTRACT: This research demand to understand the similarities and differences between the formation processes of a german Bildungsroman and that applied to contemporary brazilian youth literature. Thus, the concept of Bildungsroman is engaged socio-historically, understanding its characteristics, outlining its concern with formation, establishing a connection with the intentions of brazilian text.To exemplify the statements made, the novel Corda bamba (2002), by Lygia Bojunga Nunes, was used. The intention is to explain that, although the training in this literature is different from that established, it is still classified as a trainer. Theoretical-critical basis: Lukács (2000), Ariès (2011), Maas (2000), among others.

Keywords: Bildungsroman. Children's and youth literature. Lygia Bojunga Nunes. Comparative literature.

RESUMEN: Esta investigación busca comprender las similitudes y diferencias entre los procesos de formación de un Bildungsroman alemán y los que se aplican a la literatura juvenil brasileña contemporánea. Así, el concepto de Bildungsroman se aplica sociohistóricamente, entendiendo sus características, destacando su preocupación por la formación, estableciendo una conexión con las intenciones del brasileño. Para ejemplificar las declaraciones hechas, usamos la novela Corda bamba (2002), de Lygia Bojunga Nunes. La intención es explicar que, aunque la capacitación en esta literatura es diferente de la establecida, todavía está clasificada como capacitadora. Como base teórico-crítica: Lukács (2000), Ariès (2011), Maas (2000), entre otros. Palabras-clave: Bildungsroman. Literatura infantil y juvenil. Lygia Bojunga Nunes. Literatura comparada.

\footnotetext{
* Mestranda em Estudos Literários pelo programa de Pós-Graduação em Letras e Linguística (PPGL) da Universidade Federal do Goiás (UFG). Bolsista CAPES. http://orcid.org/o0oo-0002-3103-8381
}

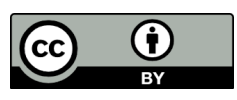




\section{Introdução}

A Literatura infantil e juvenil é alvo de inúmeros estudos acerca da sua capacidade formadora, portanto, muito se discute sobre o seu papel na formação do indivíduo, sua relação com a escola e o ensino de quaisquer que sejam os atenuantes que se liguem a tal - o ensino de uma possível moralidade civil é um exemplo disso. Equívocos e mitos acerca da função dessa literatura foram se dissipando e se transformando ao longo dos anos, de modo que se chegou a uma visão da criança como indivíduo com particularidades diferentes daquelas do adulto. Todavia, os estudos acerca da especificidade, da razão de existência e principalmente da função da Literatura infantil e juvenil, ainda é assunto discutido dentro da Academia. Para que se compreenda as peculiaridades desta vertente literária, é necessário recuperar historicamente o processo pelo qual passa, entendendo a concepção de criança e a necessidade de uma literatura destinada a elas.

Assim, faz-se necessário compreender que a concepção de criança muda à medida que a constituição de família também muda, sustentada agora pelo ideal burguês de organização econômica e social. As crianças, portanto, em meados do século XVIII (ARIÈS, 2011, p. 185), passam a ocupar e exercer um novo papel, já que, antes do surgimento da família burguesa, eram inseridas no seio da sociedade e cumpriam papéis semelhantes aos adultos. O apego à criança e à infância foi construído socialmente e passou por fases evolutivas que, gradativamente, foram transformando a percepção que os adultos tinham dos infantes.

Ariès (2011) descreve o papel moral que o texto escrito desempenhou para educação e orientação das crianças, como no capítulo "Do despudor à inocência”, em que o historiador apresenta um trecho retirado de um tratado de civilidade, usado para ensinar gramática, pronúncia e escrita correta de palavras e, principalmente, a ler (op. cit., p. 148). A literatura era usada como pretexto, como instrumento para ensinar ideais 
- principalmente de moralidade cristã - e ajudar no ensino escolar. Essa prática, de ver a literatura como pretexto para ensinamentos pedagógicos, que começa no século XVIII, produz grande efeito nas produções posteriores, que ainda vão tomar como função dessa a veiculação de conteúdos moralizantes e edificantes.

Perrotti (1986), em O texto sedutor na literatura infantil, discute a visão imposta à literatura infantil e juvenil de sempre aparecer restrita àquilo que é didático, utilitário. Assim, reflete sobre o utilitarismo na literatura, entendido como a tendência de enxergar e produzir literatura infantil a partir de uma função ligada ao ensino. O autor, discutindo as diferenças entre os discursos estético e utilitário, explica que esse último sempre tendia a "oferecer atitudes morais e padrões de conduta a serem seguidos, ordenando os elementos narrativos em função de tal finalidade exterior" (PERROTTI, 1986, p. 117).

Turchi (2008), por sua vez, aponta as tendências contemporâneas da literatura infantil em contraste com o que era feito nas décadas de 1970 e 1980. Segundo a estudiosa, a reflexão sobre o panorama histórico da literatura infantil e juvenil auxilia na compreensão da produção literária em 1970 como período de consolidação da área, uma vez que percebe que as obras passam a obedecer a uma organização temática e estilística específica, e isso é reflexo do momento histórico-literário brasileiro e das novas condições do leitor (TURCHI, 2008, p. 2). Dessa forma, a nova leva de autores que publicam obras para crianças e jovens a partir de 1970 tendem a oferecer narrativas que aguçam o senso crítico dos jovens leitores.

Dessa forma, o intuito da presente análise é o de, dada essa característica da Literatura infantil e juvenil de tratar de assuntos que contribuem para o aprendizado do jovem leitor, propor uma discussão aliada à ideia de Bildungsroman. Essa literatura parece, portanto, representar e contribuir para o desenvolvimento do romance de formação na literatura contemporânea brasileira. Segue-se, então, a definição de Bildungsroman.

Bildungsroman é um termo alemão que foi instaurado na crítica literária em 1810 pelo teórico Karl Morgenstern e amplamente difundido através da obra do filósofo Wilhelm Dilthey, em 1870; como explica Wilma Patrícia Maas, em seu O cânone mínimo: o Bildungsroman na história da literatura, de 2000. Assim, segundo a pesquisa e 
discussão desenvolvida pela teórica, a partir dos estudos de Morgenstern é que se entende o conceito como expressão de um "espírito nacional alemão", aliado primordialmente ao romance goethiano Os anos de aprendizado de Wilhelm Meister (2009) e à concepção ali desenvolvida de educação, mas uma educação em sentido de aprimoramento humano.

Assim, os romances de formação parecem buscar sempre o desenvolvimento, a formação do indivíduo, pensando na trajetória, nas provações e situações que ele passa, a fim de alcançar um outro patamar de sua formação, que agiria como a conclusão desse processo formador. Concomitantemente, estaria também imbuída no processo de apreensão por meio do literário, a formação do leitor. É importante entender, também, que o Bildungsroman parte da ideia de processo, que todas essas etapas se interligam de modo a contribuir para um aprimoramento humano, em que o indivíduo compreenda a si, ao mesmo tempo que compreende o mundo e como este influencia em sua vivência.

João Luís Ceccantini quando, em Vida e paixão de Pandonar, o cruel de João Ubaldo Ribeiro (1993) - um estudo que envolve a produção e a recepção de jovens leitores em relação à obra de João Ubaldo Ribeiro - pondera acerca da iniciação do jovem leitor naquilo que ele chama de "experiência do mundo", diz que é importante perceber na tradição do romance ocidental e no que diz respeito, principalmente, à Literatura infantil e juvenil, uma tendência, uma tradição que se associa ao “'subgênero' literário denominado Bildungsroman" (CECCANTINI, 1993, p. 31-33). Para o ensaísta, o Bildungsroman é o romance no qual se trata a fase de formação de determinado indivíduo, é o momento pelo qual, esse mesmo indivíduo se descobre através das ações, situações, provações, percalços e outros.

Larissa Warzocha Fernandes Cruvinel, em Narrativas juvenis brasileiras: em busca da especificidade do gênero (2009), acrescenta aos estudos apresentados uma análise da ligação entre a literatura juvenil e o Bildunsgroman, aspecto recorrente na literatura juvenil brasileira e estrangeira contemporânea. Frequentemente, segundo a autora, há na literatura juvenil a preocupação com a formação para a vida do/a protagonista representado/a na narrativa, de modo que a aprendizagem tematizada na obra vai além do utilitarismo que marcou o gênero até mais ou menos a década de 70. 
Ambos os pesquisadores acima citados - Ceccantinni e Cruvinel - contribuem para um entendimento dessa associação do Bildungsroman às produções de Literatura infantil e juvenil, uma vez que permitem traçar um panorama claro da necessidade e preocupação dessas produções em contribuir para formação do indivíduo. Assim, se explica a razão desta pesquisa em ponderar acerca das semelhanças, em um movimento quase que de tradição, dessa produção alemã para aquelas brasileiras. Constitui-se como interesse desta análise dizer também acerca das diferenças observadas na forma genesíaca do Bildungsroman em contraste a essa empregada na contemporaneidade, em específico nas produções concernentes à uma literatura com um público leitor delineado.

Discutir-se-á através de Corda bamba (2002), ${ }^{1}$ de Lygia Bojunga Nunes, o processo de formação da personagem Maria e a maneira pela qual a autora opta por construir o processo de formação da personagem em questão. Assim, é por meio da análise do romance bonjuguiano que se apontará as semelhanças e as diferenças entre os processos de formação goethiano e aquele aplicado à literatura infantil e juvenil contemporânea; a fim de explicar que, apesar da formação nessa literatura se dar diferentemente daquela estabelecida pelo ideal alemão, ainda sim se classifica como formadora, mesmo que não chegue a uma espécie de conclusão estabelecida na maioridade.

\section{O processo sócio-histórico e o conceito de Bildungsroman}

O século XVIII é marcado por inúmeras mudanças, desde aquelas que influenciaram econômica e cientificamente até aquelas que disseram respeito à forma como o homem se enxerga e se posiciona no mundo. Há, portanto, transformações na agricultura, uma nova organização de divisão social do trabalho, as cidades ganham cada vez mais adeptos e cresce o mercado industrial. Ascendem neste período ainda as

\footnotetext{
${ }^{1}$ Este romance recebeu o prêmio de livro Altamente Recomendável para o Jovem, pela FNLIJ, em 1979.

Revista Investigaçōes, Recife, v. 33, n. 1, Dossiê: Literatura Contemporânea de Língua Portuguesa, p. 1 - 26, 2020 ISSN Digital 2175-294X
} 
manifestações das sociedades iluministas, que buscavam na razão seu item norteador, de modo que todo o conhecimento deveria ser pensado, então, a partir dela. O homem moderno torna-se um homem motivado pela razão, fazendo com que os princípios do conhecimento também assim o fossem. Desse modo, dada essa concepção de estruturação e organização social e econômica, o sistema capitalista começa a se sustentar e a burguesia comercial no Ocidente se consolida, principalmente na Europa. Dessa forma, as classes sociais se reorganizaram de modo que fossem compatíveis com as necessidades impostas pela organização da vida moderna. Com a nova visão do homem acerca de si e do seu papel social, as demandas dessa sociedade mudam, e isso não é diferente em relação à literatura.

É neste contexto de mudanças socioeconômicas e firmação do indivíduo inserido em uma nova ordem social, exercendo novas funções e tendo uma consciência diferente de si, que se firma o romance enquanto gênero literário. O crítico e historiador literário Ian Watt, em seu $A$ ascensão do romance (2010), considera que em meados do século XVIII, na Inglaterra, o romance moderno alinha suas primeiras estruturas. Para comprovar a afirmação, traz os nomes de escritores como Samuel Richardson, Daniel Defoe, Henry Fielding, Denis Diderot, entre outros, explicitando o trabalho desses com o que é pertencente à uma noção de realismo, uma volta para aspectos do real e que permitiam um maior labor e tratamento das noções de individualidade do gênero.

Destarte, essa nova experiência social - que pensa na experiência do indivíduo, sem necessariamente estar ligada a um desígnio maior, como era matéria da epopeia permitiu que o romance se estabelecesse como uma tendência que relaciona e se interliga com a experiência da vida moderna, que respalda e valoriza toda e qualquer experiência humana. $\mathrm{O}$ romance parece valorizar, principalmente, a realidade que a obra literária pretende tratar e refletir; isso se interliga, principalmente, com a tendência de exprimir aquilo que é particular. Isso acaba por permitir que o homem, enquanto esse ser individual, seja matéria e assunto de romance, sem estar aliado a nenhuma outra intenção que não seja tratar dele e de suas experiências.

Dada a característica do romance de estabelecer diálogo com aquilo que é individual, se torna possível pensar em narrativas que trazem personagens melhor 
explicitados, e se delineiam a partir de uma personalidade traçada, dando à história um teor bem mais próximo ao real. Aqui se nomeiam personagens, elas não precisam mais estar ligadas à construção de tipos literários, ou personalidades históricas. Assim, os romancistas começaram a desenvolver suas personagens a um nível bem mais individualizado e a "batizarem suas personagens de modo a sugerir que fossem encaradas como indivíduos particulares no contexto social contemporâneo" (WATT, 2010, p. 20).

Rosana Munette da Silva, em sua tese O Bildungsroman e a circularidade dos motivos memoráveis em romances de Lygia Fagundes Telles (2014), aborda, rapidamente, a questão da ascensão no romance e diz que os romancistas apresentavam obras que se voltam principalmente para ações individuais - ação essa que não é vista anteriormente nas produções literárias -, com base ou na realidade, aquela que parte da verossimilhança, ou com enredos completamente ficcionais, e tudo isso pensando em tentar representar a experiência pessoal, única. Há, portanto, maior atenção da parte dos escritores em criar personagens mais individualizadas, mais representantes do próprio ambiente, seja ele com base naquilo que é real ou puramente ficcional. Silva (2014) afirma que essa preocupação, quando aliada ao tratamento que o tempo tem no romance, permite a construção de personagens que começam a se tornar temporais, o que faz com que haja um interesse no desenvolvimento da personagem diante do tempo. O lugar para o qual a personagem caminha é tão importante quanto o caminho que ela passa para chegar até lá.

Pensando nessa trajetória do romance como um gênero que exprime os anseios e a organização da vida burguesa e que, partindo disso, constrói na literatura um lugar em que o indivíduo e suas experiências - essas frutos da sua própria vivência, sem ação externa outra que o próprio viver - figurem importância. Nessa nova visão acerca da postura do homem frente ao contexto em que ele se insere, o próprio homem, enquanto indivíduo, é responsável pelos caminhos, ações e atitudes que toma. Ele se desenvolve e o romance procura mostrar esse processo de transformação. É o gênero que exprime a própria experiência de transformação e ascensão da sociedade burguesa. 
Assim, entendendo a importância do processo de firmação sócio-histórico do romance, enquanto gênero nascido da necessidade da representação daquilo que era real e experienciado pela burguesia, é que o Romance de Formação, Bildungsromam, se instaura. O Romance de Formação, portanto, está completamente ligado ao processo socioeconômico de ascensão da burguesia, mas especificamente da sociedade burguesa alemã. É, dessa forma, um representante direto da organização política, histórica, social da Alemanha à época, e reflete uma tendência alemã de tentativa de construção de uma identidade nacional, que por essas razões, a um primeiro contato, parecia poder refletir apenas esse contexto.

Segundo os estudos realizados por Maas (2000), a palavra Bildungsroman associa dois momentos de grande relevância para a conjectura histórica, tanto europeia, quanto alemã. Assim, a classe média alemã se organizava a fim de emancipação política, incentivando o processo de busca tanto pelo autoaprimoramento, quanto por uma educação que fosse universal. Tais características permitiram o reconhecimento do romance como um gênero literário apto para representar o povo burguês e seu ideário. E, explica ainda mais a autora, que o termo morfologicamente, e a partir de tradução mais ou menos direta, traria dois ideais claros do que constituiria a ideia: Bildung como formação e Roman como romance. Trata-se, portanto, de um texto literário feito à medida de romance que teria como função exercer dentro e fora da história, formação. Essa por sua vez, contribuiria tanto para a construção da personagem como, concomitantemente, afetaria o leitor. Assim, a formação do jovem burguês e seu aperfeiçoamento individual e social estavam bem retratados diante de um gênero que em sua concepção compreendia bem os anseios que surgiam, como sugere Maas.

Tendo em vista essa concepção de formação que parece se por nos romances que pertencem à essa vertente de produção literária, o termo Bildungsroman foi apresentado à crítica pela primeira vez (como já exposto neste artigo) pelo teórico Karl Morgenstern, que não só propõe que haja nesses romances uma representação do aprimoramento do homem enquanto indivíduo, como também estabelece que a obra de Johann Wolfgang von Goethe, Os anos de aprendizado de Wilhelm Meister, é a realização perfeita disso. 
Em conferência na cidade de Dorpat, parte da Confederação Alemã, Morgenstern afirma o teor com finalidade de aprendizado que os romances de formação possuem e defende a ideia de que essas obras permitiam um aprendizado voltado para a consolidação de uma moral, e a formação também do caráter (MAAS, 200o, p. 42). Dessa forma, o comentário feito pelo filólogo permitiu que se firmasse uma relação entre a concepção de Bildungsroman e a formação do caráter, aquele primeiro sendo, portanto, veículo para a propagação do segundo. O termo Bildungsroman assume, portanto, um caráter voltado para o pedagógico.

Outro crítico que trata do Romance de Formação é o húngaro Georg Lukács. O autor acredita que o romance goethiano, Os anos de formação de Wilhelm Meister, é um exemplo perfeito de realização nessa vertente de textos. Aqui, de acordo com o teórico, as personagens dos romances não recebem mais uma trajetória respaldada por graça de divindades; a trajetória passa a ser produto da individualidade, o próprio personagem é quem se torna responsável por aquilo que acontece. Lucáks (2000), depois de estabelecer a existência de três tipos diferentes de romance, afirma que a terceira forma - o Romance de Formação - é aquela que estabelece como tema a reconciliação do indivíduo com a realidade concreta, perpassando pelo processo de experiências vivenciadas que o forma (LUCÁKS, 200o, p. 138). O indivíduo representado no romance ao fim de seu percurso se enxerga e se insere como parte da realidade estabelecida; ele deve, para tanto, superar aquilo que lhe é interior e tornar-se parte ativa do mundo, deve atuar a favor da sociedade e dos anseios que insere, como nos explica a pesquisadora Larissa Cruvinel (2004, p.14), em sua dissertação. É, assim, um exemplar perfeito de homem.

Assim, a educação da personagem se dá a partir do confronto com o mundo que lhe é exterior. É inserido em seu próprio contexto que a personagem erra, aprende e se molda, terminando um homem transformado que volta para esse mundo, em uma posição diferente daquela em que começa. Marcus Vinicius Mazzari, em apresentação à edição de 2006 de uma versão traduzida para o português de Os anos de aprendizado de Wilhelm Meister, discorre sobre o processo de formação na citada obra e a percepção da crítica ao longo dos anos em relação a concepção de Bildungsroman em paralelo a isso. Não obstante, discute a afirmação hegeliana, apresentada em Cursos de estética II, de 
que o romance, enquanto gênero, teria como tema esse processo de educação feito a partir da inserção e enfretamento do mundo exterior, afirmando que, assim, a experiência apresentada no romance goethiano se tornaria "mais explícita", haja vista que essas lutas se representariam no mundo moderno como os próprios anos de aprendizado, é, como explica Mazzari ao citar Hegel, o indivíduo quem em contato com o exterior termina se moldando em outro.

Portanto, o conceito de Bildungsroman, em gênese, estava ligado ao romance Os anos de aprendizado de Wilhelm Meister e a forma como esse se constitui; é o modelo perfeito deste tipo de produção, pois "coloca no centro do romance o ser humano, a realização e o desenvolvimento de sua personalidade, com uma clareza e concisão que dificilmente um escritor haverá conseguido em alguma outra obra da literatura universal.” (LUKÁCS 2 , 2009, p. 587).

Os anos de aprendizado de Wilhelm Meister conta, portanto, a história de um jovem burguês, que mesmo pertencente, e até mesmo destinado a uma ocupação em um núcleo social que se voltava para o mercado, opta, na tentativa de formação, por caminhos que fogem a isso. Há nesse romance goethiano, por parte da personagem, um apreço e tentativas incontáveis de se formar. Assim, o romance tem grande enfoque na trajetória dessa personagem, no processo, no modo como ela aprende. É o conhecimento universal que se busca ali.

Meister, em razão da necessidade de se conhecer, aliada à certeza de que isso se daria a partir do seu envolvimento com o teatro, inicia seu percurso imbuído em uma esfera totalmente individualizada de percepção de si e do mundo - há a certeza do teatro como um destino à contramão daquilo que fora idealizado para ele (ser comerciante). Quem a personagem é, está completamente ligada àquilo que ela pensa ser seu. A feitura do teatro é, para Wilhelm, o molde e o único caminho a ser seguido. Ele está completamente imerso em uma idealização ingênua que as certezas da juventude lhe imputam.

\footnotetext{
${ }^{2}$ Texto de 1936, traduzido de Georg Lukács, Werke, vol. 7: Deutsche Literatur, "Goethe und seine Zeit", Neuwied/Berlim, Hermann Lutchterhand, 1964. Retirado da edição da Editora 34, de Os anos de aprendizados de Wilhelm Meister, em posfácio, de 2009.
} 
Influenciado por essa questão de natureza dual, (as vontades do jovem e os desígnios de conjectura social, exposto principalmente na figura do pai) e a fim de procurar uma conciliação dessa situação, Wilhelm Meister viaja, partindo, assim, da casa paterna. Aquele lugar parecia representar ao mesmo tempo que incerteza, alguma segurança. Essa saída é significativa e figura, para fins também desta análise, um ponto importante da jornada presente no romance, em que o indivíduo se insere com intuito de formação. O desvencilhamento desse lugar fixo e representativo de segurança, parece ser uma escolha consciente da busca de independência, uma tentativa de se formar.

Durante o seu percurso, Meister passa por uma série de provações, situações infortuitas, traições de diversas ordens, vivencia momentos traumáticos, entre outros. Tudo isso parece contribuir para que ele se perceba inserido nesse mundo, para que ele se dê conta da jornada e entenda que esse processo doloroso, de provação, faz parte das peripécias da vida. Há, aqui, uma percepção maior do ser em associação com o mundo. É o indivíduo inserido em seu contexto, que atua, depois desse despertar, em função desse mesmo contexto. Esse momento parece ser decisivo e importante para a concepção do Romance de Formação, pois contribui para tomada de consciência do aprendizado em si; não mais aquele que pensava em resoluções individuais, mas sim um que compreende o homem como integrante de uma coletividade. Lukács (2009, p. 592) sobre isso afirma que:

[...] o ponto de transição decisivo para a educação de Wilhelm Meister consiste precisamente em que ele renuncie sua atitude puramente interior, puramente subjetiva, para com a realidade, e chegue à compreensão da realidade objetiva, à atividade na realidade tal como ele é: Os anos de aprendizado de Wilhelm Meister é um romance de educação: seu conteúdo é a educação dos homens para a compreensão prática da realidade.

Assim, a partir desse processo em que a personagem reconhece o aprendizado e a importância da trajetória em que se insere, e deixa as convicções da situação anterior ao amadurecimento, essas individuais, se reconhece como parte ativa da sociedade. Nesse sentido, Mazzari (2009, p. 595) explica que a "ideia educativa do Wilhelm Meister é a descoberta dos métodos com a ajuda dos quais se despertam essas forças adormecidas em cada indivíduo, que preparam para a atividade fecunda, o 
conhecimento da realidade, o conflito com a realidade, que fomentam aquele desenvolvimento da personalidade.” Isso demonstra uma aprendizagem efetiva, uma realização e uma formação que compreende as ações do mundo externo.

Larissa Cruvinel (2004) comenta a existência de uma tentativa, uma perseguição de uma completude do humano em um esforço de se relacionar e compor um quadro maior externo, a uma implementação do contexto social, do mundo como um todo. Assim, afirma que Meister deixa "seus anseios puramente juvenis para ingressar na vida adulta, passa por uma dialética dos contrários, representados em pulsões subjetivas ligadas à infância e às pulsões objetivas de uma fase de amadurecimento, para depois um conjunto de provas, entrar em outra etapa da existência” (op. cit., p. 26). O Romance de Formação, portanto, pretende sempre procurar a integração, o amadurecimento do indivíduo, de modo que esse possa ser e fazer parte da realidade, viver uma nova fase em conjunto com o mundo externo.

A presente discussão compreende, portanto, a gênese do termo Bildungsroman advindo da produção estética e conteudística de Os anos de aprendizado de Wilhelm Meister, além de compreender também que esse estava unido à conjectura histórica, política e social da Alemanha e pelo romance tratar desse processo de formação a partir e para a sociedade em que o indivíduo se insere. Todavia, é justamente por haver no Romance de Formação essa possibilidade de se encarar as produções como a trajetória formadora do indivíduo inserido em contexto especifico, que essa discussão se debruça na obra Corda bamba.

Essa afirmação parece se sustentar, no que Maas (2000) afirma ao dizer que existe a possibilidade de uma permanência, uma espécie de continuação do Bildungsroman se pensarmos nesse coligado a diferentes contextos sociais, culturais e históricos - em razão da condição primária do termo de estar associado a contextos de realidade social específicos. Assim “é apenas pela compreensão do Bildungsroman como um objeto formado predominantemente por manifestações discursivas que se poderá legitimar a existência de um Bildungsroman diferente a cada período histórico-cultural, a cada núcleo formador de significado" (MAAS, 200o, p. 262). 
A ideia de Bildungsroman surge, então, atrelada à todas essas situações elencadas acima que se tornam contemporâneas a essa tentativa de instaurar um caráter nacional da literatura alemã, arroladas às condições históricas, culturais e literárias da Europa. Partindo desse conceito, e que entendemos como a gênese do termo Bildungsroman visto de maneira paradigmática no romance Os anos de aprendizado de Wilhelm Meister, entende-se, a partir de Maas (2000, p. 13), que o termo se torna um “conceito produtivo" para outras literaturas e não só as europeias, além de se estender e ramificar durante os anos, influenciando em produções literárias mais jovens.

O homem é um ser mutável, e como o processo de formação pauta-se no próprio homem, por consequência, assim também será. Sempre haverá uma nova fase, um novo ideal de formação, uma constante associação do "ser e do mundo, as novas etapas da vida e os diferentes contextos socioculturais" (CRUVINEL, 2004, p. 27). Desse modo, não se excede a análise quando busca representar e entender a Literatura infantil e juvenil como campo literário contemporâneo brasileiro que permite produções à luz do Bildungsroman, dada a preocupação dessa literatura de também formar; mesmo que acabe o realizando de maneira um tanto quanto distinta da forma genesíaca.

\section{A feitura do Bildungsroman na Literatura infantil e juvenil - Uma análise de} Corda Bamba (2002), de Lygia Bojunga Nunes

Alguns trabalhos no campo crítico da Literatura infantil e juvenil perceberam a tendência desta a produzir e recriar esteticamente o Bildungsroman; essas pesquisas pautam-se pela ideia de que a Literatura infantil e juvenil, por si só, já são o lugar em que os escritores se preocupam e procuram contribuir com a formação dos jovens leitores. Assim, a preocupação formadora da Literatura infantil e juvenil volta-se para o humano - é a formação humana dos leitores que a preocupa. Isso é, por vezes, matéria de muitas das produções que se inserem nesse paradigma; apresentando uma criança ou um adolescente, em um contexto, muitas das vezes, representativo desse universo 
infantil, que aprende e se forma em consonância com o mundo exterior. Essa personagem se descobre psicológica e socialmente e se forma, através de experiências também comuns ao universo do jovem leitor.

As literaturas pertencentes a esse viés de concepção literária buscam, portanto, contribuir com a educação dos jovens que, à medida que leem um romance que apresenta personagens com os quais ele pode se identificar, também percebem e descobrem revelações a seu respeito como indivíduo e aprendem. É nesse sentido que o Bildungsroman se insere no contexto da Literatura infantil e juvenil, uma vez que há uma integração do indivíduo com o contexto social que pertence. A aprendizagem é, por vezes, a intenção; e por assim ser, à medida que a personagem enfrenta o seu próprio caminho e se insere de volta no mundo, abre a possibilidade para que isso aconteça também ao leitor.

Deste modo, Cruvinel, no artigo Literatura juvenil: em busca de uma especificidade, de 2008, discute, rapidamente, a especificidade das narrativas juvenis e as particularidades do gênero à luz de perspectivas, como o público-alvo, os aspectos formais às narrativas juvenis, entre outros, ao passo que acrescenta aos estudos apresentados uma análise da ligação entre a literatura juvenil e o Bildungsroman. Tendo como enfoque essas discussões, a autora completa que ao desenvolver esses estudos percebe "uma preocupação com a educação, com uma aprendizagem não escolar, na perspectiva de formar um ser humano mais preparado para enfrentar suas dificuldades seria algo recorrente na Literatura juvenil brasileira” (op. cit., p. 5). A afirmação se encerra na Literatura juvenil apenas, mas essa afirmação caberia também à produção infantil, haja vista a sabida tendência educativa desse segmento da literatura.

Outro aspecto a ser levantando é a transformação da visão da Literatura infantil e juvenil que começa, a partir de meados da década de 1970, a prezar por um desenvolvimento estético das produções que permitissem uma maior participação crítica do leitor, além de não mais reduzir o processo formador dessas a conteúdos moralizantes, a serviço da educação e formação escolar e sempre carregador de um tom autoritário, da visão do adulto em detrimento daquela da criança/adolescente. Dessa forma, há uma preocupação social por parte dessa literatura: a criança passa a ser vista 
como um ser completamente capaz de absorver e compreender os mais variados tipos de produção literária. Assim, surge a necessidade de romper com a normatização e a cristalização do modelo precedente de literatura destinada às crianças e jovens, além de uma preocupação com a reflexão crítica acerca do papel de formação da sociedade. Tal característica influencia na ideia de aprendizagem como esse caminho necessário haja a vontade de vencer determinados obstáculos, sejam eles coletivos ou individuais.

Portanto, aliada às discussões teóricas levantadas, entende-se que a Literatura infantil e juvenil é um ramo da literatura brasileira contemporânea que permite um desenvolver do Bildungsroman, já que contribui na construção do indivíduo. O duplo de imagens que se constrói nas obras pertencentes a ela faz com que haja uma interação intrínseca entre leitor e personagem - à medida que aquele primeiro pode aprender paralelamente ao segundo.

Esta pesquisa entende, portanto, que existe a necessidade nos Romances de Formação de uma personagem que empreenda um percurso em que haja transformação, aprendizado. Esse, por sua vez, é marcado por acontecimentos simbólicos que contribuíram para a conclusão do trajeto. Assim, normalmente parece haver um momento de inocência e/ou confusão em relação à própria formação, depois o afastamento de um lugar que figura estabilidade (a casa dos pais em Wilhelm Meister, por exemplo). Temos também, como parte do processo, as provações que contribuem para a formação, sejam seus resultados positivos ou não e que se associam à uma tomada de consciência acerca do aprendizado. Por fim, chega-se em um determinado momento em que aquele que empreende o caminho se vê reintegrado e completo de alguma forma.

Além disso, defende-se aqui e através do romance bojunguiano Corda bamba, a ideia de que em obras pertencentes à Literatura infantil e juvenil o processo de formação não precisa terminar na maioridade, na vida adulta. Aqui, a personagem criança ou adolescente consegue se formar ainda nesse período marcado da infância; ela sai de um estado primário e consegue chegar em uma outra fase de amadurecimento sem necessariamente precisar vivenciar a maturidade, ao contrário do que é apresentado em Os anos de aprendizado de Wilhelm Meister e amplamente retomado pela crítica do Bildungsroman em gênese. 
Isto posto, é que se empenha a análise do romance Corda Bamba (2002), de Lygia Bojunga Nunes, com o intuito de elucidar a discussão levantada nas páginas anteriores deste artigo. Para tanto, analisar-se-á o percurso que a personagem, uma criança, empreende de modo que haja nela um amadurecimento psicológico e sentimental frente às vicissitudes da perda do processo de orfandade e a nova condição socioeconômica.

O romance narra a história de Maria, uma menina de dez anos de idade que, após perder os pais, Márcia e Marcelo, em um acidente de trabalho no circo - ambos eram equilibristas e aceitam, por razões financeiras, se apresentarem sem rede de segurança - vai morar com a avó, Dona Maria Cecília Mendonça de Melo, em um apartamento em Copacabana. A menina chega, à casa da avó, recém-saída de uma crise emocional, em que ela, acionando defensivamente, oblitera as semanas posteriores à morte dos pais. A convivência das duas não auxilia em nada a confusão e o desemparado sentidos por Maria; além de possuírem personalidades distintas, avó e neta são representativas de classes sociais distantes uma da outra, fazendo com que as coisas com as quais elas se importam não tenham o mesmo lugar - a percepção do teor artístico do circo é um exemplo gritante disso. Essas diferenças socioeconômicas afetam a percepção do mundo das personagens, e parecem ser razão norteadora de ações e situações apresentadas no romance, como por exemplo o afastamento de Maria e de seus pais da avó, que não aceitava o casamento em razão da diferença social dos cônjuges.

A narração, ao mesmo tempo que começa com a chegada de Maria nesse novo ambiente, dada sua confusão e seu estado primário de ignorância e esquecimento, volta em situações passadas, de modo que consiga compreender as ações que a levaram até ali, além de contribuir para o processo de luto e seu amadurecimento - este interior, psicológico e principalmente emocional, frente a todas essas circunstâncias advindas de sua história. Simbolicamente, essas etapas aparecem representadas a partir do momento em que Maria estende a corda (a garota, como os pais, cultiva as habilidades e pratica a arte do equilibrismo) entre dois prédios, da janela de seu quarto para uma janela, "uma janela diferente das outras janelas todas; uma janela que ficava dia e noite aberta; uma janela arredondada em cima, que nem um arco" (NUNES, 2002, p. 25) e emparelhado à ela, um andaime. 
A janela dá em um corredor com seis portas de cores diferentes, em cada uma delas há uma cena que compõe descobertas, fatos de sua vida, dos pais e avó. Maria precisa ver, lidar e compreender as coisas que as portas mostram. Nesse processo simbólico de ir e vir, de um prédio ao outro, trabalhando com as experiências passadas, a menina também se vê participando de situações imersas no presente, como a construção de amizade com Quico (neto de Pedro, que por sua vez é marido da avó), as aulas particulares e o deslanchar tímido do relacionamento com Maria Cecília.

É a partir do contexto explicado que Maria inicia seu processo de formação, pois à medida que se empenha em ir descobrindo e rememorando o passado, através do explorar das portas, vai também nas ações que desempenha no presente, construindo seu caminho para atingir uma unidade de si mesma. Esse processo, em si, já permite que se recupere aspectos de construção da conjectura do Bildungsroman, uma vez que o romance se constrói intentando o amadurecimento de Maria.

O enfrentamento desses obstáculos apontados - a confusão que sente e o desamparo depois da morte dos pais -, a coragem de lançar a corda, se equilibrar e atravessar as portas junto à vontade de aprender com a professora Eunice, o conforto que sente junto de Quico e o processo de compreensão da avó contribuem para o equilíbrio interior da personagem e, consequentemente, a sua harmonização com aquilo que é externo, a nova situação em que se encontra, órfã, prostrada em uma classe social diferente àquela de seus primeiros anos, uma Maria que aos poucos vai se acostumando, vai abrindo as portas, "às vezes abria uma porta só, às vezes abria duas ou três, variava o jeito de acostumar" (NUNES, 2002, p. 122). Passado esse processo e vinda com ele a compreensão de si, Maria, em um processo simbólico, encontra novas portas e decora tudo lá dentro, com coisas que pretende fazer e, à medida que um quarto se enche, uma nova porta surge para que ela continue a preencher o espaço vazio.

Estabelecida aqui, portanto, a existência de um trajeto que intenta a formação do indivíduo em concomitância com um despertar, um reintegrar-se naquilo que lhe é real, como noção necessária às produções da vertente literária Bildungsroman, é que se estabelece, na jornada de Maria, como situação primeira e principiadora da personagem, em seu processo de formação, a saída do circo, lugar que simbolizava a proteção e a 
segurança paternal, para a ir à casa da avó. O fato de ir morar na casa da avó tira a menina de um lugar de conforto ao lado de Barbuda e Foguinho (amigos de circo da menina e que cuidaram dela da morte dos pais até estar sob a tutela da avó) e a insere em lugar de desemparo. Assim, saída desse estado, é que Maria começa, gradativamente, a abrir as portas e a buscar as respostas, o equilíbrio de seus anseios. Talvez não tão conscientemente quanto Wilhelm Meister acerca da sua busca de formação, mas ainda assim figura uma tentativa disso, haja vista que ela, depois de ponderar sobre o assunto, lança a corda e decide se equilibrar:

Maria puxou a corda com força pra ver se estava bem presa. Esticou ela bem. Se debruçou na janela; parecia que estava amarrando a corda. [...]

Maria levantando o arco; nem olhando pra baixo (era pra não lembrar que tinha um apartamento em cima do outro - nove - até chegar no chão?); só olhando pro fim da corda lá na antena de televisão. (NUNES, 2002, p. 42 e 43, grifo nosso)

Apesar de o narrador contar todo esse processo por meio da perspectiva de Quico, e não deixar claro se a personagem está sonhando ou acordada, esse fato não altera a importância da passagem, não só porque esta é a primeira de outras vezes que Maria atravessa, se equilibrando entre os prédios, como também a construção dessa trajetória é simbólica e está inserida no processo do imaginário infantil; não se pode, entretanto, aliar esse conceito à uma alienação do real, mas sim resultado de um processo paralelístico, em que o real, ou melhor, a leitura dele passa pelo imaginário. Aqui, e em Corda bamba como um todo, o imaginário funciona como um meio que leva a compreensão daquilo que é meandro na realidade. Essa ideia se alia aos estudos de Jacqueline Held e a forma como essa se posiciona acerca dos elementos que compõe e caracteriza o imaginário infantil, em seu O Imaginário no poder (1980), não como aquele que vem com a intenção de esquecimento, de pura diversão que busca desviar as crianças de ater ou entender problemas que não aqueles do universo infantil.

Apresentada, assim, a personagem Quico é que se torna possível tratar de outro aspecto que instaura semelhança entre os elementos de tradição constitutiva de Bildungsroman e a produção bojunguiana. Assim, apesar de haver outra criança no romance e que vive lado a lado com Maria, é a formação dela que se encontra em 
primeiro plano. Ela é o indivíduo que é posto em posição de destaque e que vai empenhar a função exemplar, que dará margem para o espelhamento e apreensão do leitor. Sobre isso Lukács (2000) esclarece, através de observação acerca da figura do herói, que esse a figura selecionada pelo romance, é quem filtra e reflete simbolicamente as vivências sociais.

Corda bamba é uma obra temporalmente distante de Os anos de aprendizado de Wilhelm Meister e trata do processo de formação de uma maneira não tão semelhante do processo de formação, haja vista que a trajetória de Maria está imbuída de ritos iniciáticos e elementos simbólicos que marcam o caminho de aprendizagem e desenvolvimento dessa personagem. Cruvinel (2004), sobre a trajetória simbólica nas obras de Lygia Bojunga aliada ao Bildungsroman, explica que nos processos de formação que se dão por meio da iniciação simbólica a ideia de progredir, lapidar-se também é um objetivo central, mas que se relaciona à uma "morte simbólica" que encerra uma fase e faz com que a personagem esteja pronta para uma outra - um renascer. Esses processos se tornam semelhantes, portanto, haja a necessidade de progressos gradativos, de formação por meio de fases a serem superadas, a fim de inserir harmonicamente esse indivíduo em seu próprio contexto. Feita essa explicação, a pesquisadora defende que se "um dos objetivos centrais do Romance de Formação é que haja uma harmonia entre eu e mundo, a forma como vislumbramos para atingir esse equilíbrio se configura pelos ritos iniciáticos" (CRUVINEL, 2004, p. 47).

Diante da vontade de compreender Corda bamba como representante da feitura de Bildungsroman, é que se pensa em alguns pontos cruciais presentes nessa obra que figuram elementos simbólicos e contribuem para a formação de Maria, entendendo também que a trajetória da menina intenta, mesmo que feita a partir do simbólico, formação; formação essa pautada em um indivíduo que, depois de empenhado um caminho de provações, se reintegra, transformado, à sociedade. Daí a necessidade de pensar na formação psicológica e emocional da protagonista do romance através do confronto de elementos simbólicos como a morte, o estender da corda procurando equilíbrio, o abrir das portas e a contraposição do quarto decorado pela avó e aquele vazio que ela decora, no fim da história. É uma sucessão de momentos marcadamente 
simbólicos que contribuem, um a um, na aprendizagem que Maria tem de si, da sua condição e lugar que ocupa e, principalmente, da organização do estado de ser fragmentado que estava após a morte dos pais e o ser que tende à unidade, em que ela vai trabalhando para ser.

Não se pode desconsiderar, portanto, o fato de que a protagonista deste romance bojunguiano é uma mulher e que a crítica literária estabelece a existência e a diferença de concepção de um Bildungsroman feminino. A mulher, por excelência, passa por um processo formador distinto daquele que empreenderia um homem, haja vista a conjectura de organização social e o lugar de fala da figura feminina baseada nos ideais patriarcais. Assim, o processo de construção das personagens femininas e masculinas se diferem, pois tanto o percurso quanto os objetivos e como se dá a aprendizagem possuem modos diferentes de se realizar em razão dessas figuras ocuparem, mesmo na contemporaneidade, lugares diferentes.

Dado que o Bildungsroman é uma vertente literária que se interliga intrinsicamente ao contexto social, pensa e reflete a sociedade, não é estranho que existam diferenças, então, na construção de um Romance de Formação que apresente protagonistas femininas. Todavia, não é intenção desta pesquisa se debruçar e esmiuçar questões dessa ordem, mas a ela parece necessária que se chame atenção para esse fato e que não o desconsidere, já que se trata aqui de uma pesquisa comparativa da realização do Bildungsroman, não só na Literatura infantil e juvenil, como na realização contemporânea dessa.

A Literatura infantil e juvenil, e aqui se cristaliza na realização estética de Lygia Bojunga Nunes em Corda bamba, tende a transmitir a ideia de que, depois de empenhado o trajeto formador, o resultado é proveitoso e, por vezes, feliz, em razão da reintegração daquele indivíduo na organização social representada no romance. Paralelamente, a formação do leitor também acontece e esses mesmos ideais são perpassados a ele. A história de Maria é exemplar, não apenas pela identificação do leitor com a personagem, feita pelas situações que ela vive (o fato de ir morar com a avó ou a morte dos pais), mas também pelo fato de que a personagem, no início fragmentada, 
desemparada, consegue restaurar a si e se organizar, de forma consciente, a partir das concepções do universo infantil.

Os textos literários pertencentes a essa Literatura - a infantil e a juvenil -, tendem a respeitar e incentivar a criticidade do jovem leitor, apresentando uma fortuna de assuntos que vão da abordagem tradicional do sentimento amoroso até o trabalho com percepção e a compreensão diante da morte, por exemplo. Tudo isso respeitando o universo dos infantes e não imputando a voz autoritária do adulto que "sabe melhor", do adulto experiente. Assim, as produções de Lygia Bojunga e aqui, em especifico, Corda bamba, respeitam os jovens leitores e o universo infantil. Diante disso é que se entende a formação de Maria como uma forma de contribuição para constituição humana; Maria se forma humanamente, em meio e a partir da percepção de uma criança de dez anos. Dessa forma, à luz daquilo que é feito em Bildungsroman, a intenção não é de uma formação escolar. Isso se comprava durante o desenrolar do enredo em que as cenas das aulas particulares e tudo aquilo que é tocante a educação escolar de Maria ficam encarceradas na necessidade da avó de que a menina aprenda, e consequentemente, deixadas por ela em segundo plano. Quando na casa da professora Eunice, Maria se distrai com todo tipo de coisa que não as matérias dadas - é a unha da professora, o medo do cachorro que fica debaixo da mesa e não deixa que ela apoie os pés no chão. A menina pondera sobre o medo de não conseguir aprender, a impaciência da professora e à medida que a aula se estende, ela se atrapalha e fica cada vez mais nervosa. Daí o contraste no processo do aprendizado escolar e o humano, enquanto aquele primeiro causa sofrimento, é feito em tempo determinado (as aulas são interrompidas pelo despertador) e cronológico, e quem constrói o que é importante ou não, o que é necessário aprender, é uma outra pessoa que não a menina, em contrapartida, quando se aventura no corredor e do descobrir do conteúdo das portas, é Maria quem controla. Controla o que vê, quando está preparada para ver, controla a ida, além de que, o tempo quando está no corredor, é psicológico e dura conforme a necessidade dela: "Muitas vezes acordou de madrugada com vontade de ir lá. Mas também com vontade de não ir. Não ia, dormia. Duas vezes pegou o arco pra sair. Mas quando já ia saindo, mudava de ideia, ficava. (NUNES, 2002, p. 85). 
Maria amadurece frente ao sofrimento, frente às experiências dolorosas. É através de situações como o rompimento com a visão identitária, de um eu marcadamente construído pela arte circense, o fato de não se reconhecer como parte do lugar social que a avó ocupa e, principalmente, a confusão frente à morte dos pais, que a formação da protagonista se caracteriza. Decidir se equilibrar na corda e aventurar-se na janela do prédio em frente, inicia o processo de autoconhecimento. Através do desdobramento do abrir das portas, Maria vai se conectando às imagens do passado e assimilando-as de modo a completar quem é. As lembranças atrás das portas compõem um quadro em Corda bamba que preenche as lacunas na memória de Maria, dando tanto à personagem quanto ao leitor um panorama para compreensão dos eventos que levaram a garota até ali - a vida órfã na casa da avó. Mesmo que o abrir e o entrar nos quartos deem margem para a angústia, uma vez iniciada do processo de descobrimento e integração de si, Maria não consegue deixar de abrir as portas. Até mesmo quando abre a porta, que explora o evento que findou a vida dos pais, apesar do medo, ela acaba se perdendo em meio à cena que assiste no quarto, seguindo em frente.

O conhecimento acerca daquilo que se encontram atrás das portas é importante para o seu caminho de individuação e, consequentemente, seu aprendizado. Recuperar o passado, mesmo que isso signifique ter de lidar com a dor, é coisa pela qual ela tem de passar, haja a necessidade de constituição desse ser uno. Maria, fragmentada, precisa se tornar inteira de novo, e só o descobrimento de si mesma pode fazer isso. Tornando-se inteira, Maria poderá, então, reintegrar-se ao contexto, ao meio que se insere, de forma renovada. Agora, de fato, há a possibilidade de equilíbrio da protagonista e tanto o surgimento de novas portas que dão para quartos vazios no corredor, quanto a serenidade e sagacidade para resolver as novas situações que se mostram - como a decisão de pedir ajuda a Pedro, para conseguir passar as férias com Foguinho e Barbuda na Bahia - demonstram o amadurecimento da personagem e uma espécie de conclusão dessa etapa de formação. Há uma harmonia entre o ser e o mundo, aspecto esse tão caro ao Bildungsroman. A construção do romance bonjuguiano, Corda bamba, recupera boa parte dos aspectos constitutivos do Bildungsroman genesíaco, ao mesmo tempo que se adequa - como o próprio gênero parece permitir - às especificidades da época em que 
se realiza, o contexto brasileiro da Literatura infantil e juvenil. Assim, Corda bamba apresenta o processo de formação psicológico e emocional de Maria que, através de elementos simbólicos, enfrenta a dor e angústia e se forma, alcançando não só equilíbrio individual e reconstituição de si, como uma harmonização com a realidade em que se insere.

\section{Considerações finais}

Dada a apresentação e a análise teórica a respeito do Bildungsroman em consonância com a análise do romance Corda bamba (2002), de Lygia Bojunga Nunes, o presente trabalho pôde ponderar acerca da feitura do Bildungsroman na Literatura infantil e juvenil, de modo que se compreendeu que as diferenças constitutivas da forma genesíaca alemã em relação às empregadas na contemporaneidade, mais especificamente nas produções infantil e juvenil brasileiras, existem principalmente pelo caráter permissivo daquele, uma vez que sugere que a formação se dê em contribuição às necessidades formadoras de uma determinada época.

Com isso em mente, a análise compreendeu que o Bildungsroman se alia não só à época em que o romance se fixa, como também preza por um enredo que construa, de forma completa e em etapas, uma trajetória com intenção de aprendizagem e reintegração social do indivíduo que acompanha. Essa construção histórica do Bildungsroman permite que ele seja refeito dada às intenções do autor inserido em sua época.

Assim, a Literatura infantil e juvenil seria um dos ramos da literatura contemporânea que realizariam a tradição do Bildungsroman, em razão da característica intrínseca a ambos, que é aquela que intenta e preza pela formação do leitor concomitantemente à realização literária. A trajetória da personagem em um Romance de Formação é espelho para a do leitor. 
O Bildungsroman, por excelência, almeja a formação do indivíduo em consonância com o contexto em que se insere, é o ser em harmonia com o mundo. E, dessa forma, Corda bamba o faz. O processo de formação no romance bojunguiano é representativo das nuances transformadoras que a época e a autora dão ao Bildungsroman, uma vez que a trajetória empreendida pela protagonista, Maria, é extremamente simbólica. A personagem, inserida num processo de rito iniciático a partir da morte dos pais, se forma ao enfrentar situações simbólicas para recuperar a si à medida que recupera o passado. O ser fragmentado da menina, depois de aventurar-se em um corredor com portas, entra uma a uma, revivendo, absorvendo e refletindo sobre o passado e como ele a compõe.

Mesmo que a trajetória se constitua de maneira distinta, Corda bamba mantém a finalidade de formação e integração do indivíduo ao meio, perpassando por um percurso que requereu, daquela que o empreende, uma caminhada carregada de provas e enfretamento, em alguma instância, consciente delas, impregnando a jornada de um reconhecimento pessoal, um verdadeiro e pleno amadurecimento. É por meio da jornada, tal como Wilhelm Meister, que Maria consegue se reconstituir e estar pronta para reintegra-se no meio social. Assim, enquanto Meister vive experiências em um plano real, Maria tem as suas interligadas ao simbólico; além de que Maria não necessariamente precisou chegar à maioridade para atingir maturidade, o processo de formação da menina se desenvolve na extensão da infância.

Dessa forma, a finalidade é a mesma; existe o percurso, existem as intempéries e existe a intenção de formar, o que se distingue é a maneira como a personagem criada por Bojunga Nunes chega ao processo de harmonização. Essa distinção, a presente pesquisa conclui, é a maneira que autora encontra de realizar o Bildungsroman à luz da necessidade e, principalmente, da intenção que ela dispõe para Corda bamba.

A realização do Bildungsroman, na Literatura infantil e juvenil, mantém aquilo que lhe é mais importante, que é o intento de formação a partir da capacidade da literatura, de permitir que seu leitor vivencie experiências a partir dela. $O$ tema da educação é intento que partilham, e bem, ambas as vertentes literárias aqui discutidas. 


\section{Referências}

ARIÈS, Philippe. História Social da Criança e da Família. trad. FLAKSMAN, Dora. $\mathbf{2}^{\underline{\mathbf{a}}}$ ed. Rio de Janeiro: LTC, 2011.

CECCANTINI, João Luís Cardoso Tápias. Vida e paixão de Pandomar, o cruel de João Ubaldo Ribeiro: Um estudo de produção e recepção. 1993. Dissertação de Mestrado. Assis, São Paulo - UNESP.

CRUVINEL, Larissa Warzocha Fernandes. O Bildungsroman e o processo de aprendizagem em obras de Lygia Bojunga Nunes. 2004. Dissertação de Mestrado. Goiânia, Goiás - UFG.

. Narrativas juvenis brasileiras: em busca da especificidade do gênero. 2009. Tese de Doutorado. Goiânia, Goiás - UFG.

GOETHE, Johan Wolfgang von. Os anos de aprendizado de Wilhelm Meister. trad. Nicolino Simone Neto. 2ª ed. São Paulo: Editora 34, 2009.

PERROTTI, Edmir. O texto sedutor na literatura infantil. $1^{a}$ ed. São Paulo: Ícone, 1986.

LUKÁCS, Georg. A teoria do romance. Um ensaio histórico-filosófico sobre as formas da grande épica. trad. José Marcos Mariani de Macedo. São Paulo: Editora 34, 2000.

MAAS, Wilma Patrícia Marzari Dinardo. O cânone mínimo: o Bildungsroman na história da literatura. São Paulo: UNESP, 2000.

MAZZARI, Marcus Vinicius. s/n. In: GOETHE, Johann Wolfgang von. Os anos de aprendizado de Wilhelm Meister. trad. Nicolino Simone Neto. $2^{\mathfrak{a}}$ ed. São Paulo: Editora 34, 2009 .

NUNES, Lygia Bojunga. Corda Bamba. Ilustrações: Regina Yolanda. 21ㅗㅡ ed. Rio de Janeiro: Agir, 2002.

SILVA, Rosana Munette da. O Bildungsroman e a circularidade dos motivos memoráveis nos romances de Lygia Fagundes Telles. 2014. Dissertação de mestrado. Araraquara, São Paulo - UNESP. 
TURCHI, Maria Zaira. Tendências atuais da literatura infantil brasileira. XI Congresso internacional da ABRALIC. USP. São Paulo: s.n, 2008. Disponível em: <http://www.abralic.org.br >. Acesso em: 12 mai. 2019.

WATT, Ian. A ascensão do romance. Estudos sobre Defoe, Richardson e Fielding. trad. Hildegard Feist. São Paulo: Companhia das letras, 2010.

Recebido em 19/04/2020.

Aprovado em 22/o6/2020. 